\title{
MODEL PROGRAM PENGEMBANGAN DIRI DALAM MENGEMBANGKAN POTENSI SISWA DI SEKOLAH MENENGAH PERTAMA NEGERI 3 PETERONGAN JOMBANG
}

\author{
Moh. Takwil \\ ISTAI Alif Laam Miim Surabaya
}

\begin{abstract}
ABSTRAK
Program pengembangan diri adalah suatu keharusan di sekolah baik berbentuk kegiatan ektrakurekuler maupun bimbingan konseling. Hal ini bertujuan untuk menggali dan mengembangkan minat bakat siswa agar tumbuh sesuai dengan bakatnya. Penelitian ini adalah penelitian kualitatif untuk mendeskripsikan pelaksanaan program pengembangan diri di SMP Negeri 3 Peterongan Jombang. Penelitian ini merupakan jenis penelitian lapangan dengan menggunakan deskriptif analitis. Hasil penelitian menunjukkan bahwa pelaksanaan program pengembangan diri di SMP Negeri 3 Peterongan Jombang dilaksankan dengan: Pertama, Program ekstrakurekuler, di mana dilakukan dengan tiga tahap yaitu (1) Tahap perencanaan dengan mengevaluasi program ektrakurekuler tahun sebelumnya dan menghasilkan rekomendasi untuk tahun berjalan. (2) Tahap pengelompokan, di mana sebelum kegiatan dilaksanakan siswa dikelompokkan berdasarkan minat dan bakatnya. (3) Tahap pelaksanaan, yaitu kegiatan ektrakurekuler dilaksanakan pada hari sabtu dan minggu dengan didampingi oleh Pembina dan penanggungjawab dalam hal ini adalah Waka Kesiswaan. Kedua, Program bimbingan dan konseling yang dilakukan guru BK mengacu kepada kebutuhan berdasarkan penelitian atau survey minat bakat siswa. Ada empat layanan yang diterapkan yaitu: layanan dasar,layanan permintaan dan perencanaan individual, Layanan Responsif, dukungan sistem.
\end{abstract}

Kata Kunci: Pengembangan Diri, Potensi Siswa, Ekstrakurikuler, Bimbingan Konseling.

\section{ABSTRACT}

Self-development programs are a must in schools in the form of extracurricular activities and counseling. This aims to explore and develop students' interest in talents to grow according to their talents. This study is a qualitative study to describe the implementation of self-development programs at SMP Negeri 3 Peterongan Jombang. This research is a type of field research using descriptive analytic. The results showed that the implementation of the self-development program at SMP Negeri 3 Peterongan Jombang was carried out by: First the extracurricular program, which was carried out in three stages, namely (1) the planning stage by evaluating the extracurricular program of the previous year and producing recommendations for the current year. (2) The grouping stage, where before the activity is carried out students are grouped based on their interests and talents. (3) The implementation stage, namely extracurricular activities carried out on Saturdays and Sundays accompanied by the supervisor and the person in charge in this case is student time. Second, the guidance and counseling program conducted by BK teachers refers to needs based on research or student talent interest surveys. There are four services implemented namely: basic services, individual request and planning services, Responsive Services, system support.

Keywords: Self-Development, Student Potential, Extracurricular, Counseling Guidance.

\section{A. Pendahuluan}

Program pengembangan diri merupakan kegiatan pendidikan di luar mata pelajaran, sebagai bagian integral dari kurikulum sekolah/ madrasah. Kegiatan 
pengembangan diri merupakan upaya pembentukan watak dan kepribadian peserta didik yang dilakukan melalui kegiatan pelayanan konseling berkenaan dengan masalah pribadi dan kehidupan sosial, kegiatan belajar,dan pengembangan karir, serta kegiatan ekstra kurikuler. Sebagaimana yang disebutkan dalam pedoman kegiatan pengembangan diri yang dikeluarkan oleh Departemen Agama bahwa:

"Pengembangan diri diartikan sebagai proses pembentukan sikap dan perilaku yang relatif menetap melalui pengalaman yang berulang-ulang sampai pada tahap yang (otonomi) kemandirian mengenai suatu perilaku tertentu". ${ }^{1}$

Pengembangan diri siswa memiliki peran penting dalam proses internalisasi nilai-nilai dan perilaku peserta didik dan proses mengembangkan potensi dan bakat yang terpendam pada diri peserta didik. Seorang guru harus mampu menumbuh kembangkan minat dan bakat peserta didik. Mengarahkan peserta didik untuk lebih bisa mandiri merupakan suatu bagian dari tugas seorang guru. Guru sebagai fasilitator harus mampu menfasilitasi peserta didik dalam mengembangkan minat dan bakatnya. Banyak hal yang bisa dilakukan oleh guru yakni dengan kegiatan ekstrakurekuler. Sebagaimana yang tercantum dalam Pedoman Pengembangan Diri Departemen Agama tahun 2005, disampaikan bahwa pengembangan diri diartikan sebagai proses pembentukansikap dan perilaku yang relatif menetap melalui pengalaman yang berulang-ulang sampai pada tahap otonomi (kemandirian) mengenai suatu perilaku tertentu. ${ }^{2}$

Dalam peraturan Menteri Pendidikan Nasional mendefinisikan tujuan dari pengembangan diri lebih luas daripada apa yang disampaikan oleh Departemen Agama. Sebagaimana yang tercantum dalam peraturan Menteri Pendidikan Nasional nomor 22 tahun 2006 tentang Standar isi dinyatakan bahwa pengembangan diri merupakan salah satu komponen struktur kurikulum setiap satuan pendidikan, di mana disebutkan bahwa pengembangan diri bukan merupakan mata pelajaran yang harus diasuh oleh guru. Pengembangan diri bertujuan memberikan kesempatan kepada peserta didik untuk mengembangkan dan mengekspresikan diri sesuai dengan kebutuhan, bakat, dan minat setiap peserta didik sesuai dengan kondisi sekolah/madrasah.Kegiatan pengembangan diri difasilitasi dan atau dibimbing oleh konselor, guru, atau tenaga kependidikan yang dapat dilakukan dalam bentuk kegiatan ekstrakurikuler.Kegiatan pengembangan diri dilakukan melalui kegiatan pelayanan konseling yang berkenaan

${ }^{1}$ Departemen Agama, Pedoman Kegiatan Pengembangan Diri (Jakarta : 2005), 5.

I'bid. 
dengan masalah diri pribadi dan kehidupan sosial, belajar, dan pengembangan karir peserta didik. ${ }^{3}$

Pengembangan diri merupakan kegiatan pendidikan di luar mata pelajaran sebagai bagian integral dari kurikulum sekolah/madrasah. ${ }^{4}$ Kegiatan pengembangan diri merupakan upaya pembentukan watak dan kepribadian peserta didik yang dilakukan melalui kegiatan pelayanan konseling berkenaan dengan masalah pribadi dan kehidupan sosial, kegiatan belajar, dan pengembangan karir, serta kegiatan ekstrakurikuler yang dipilih sesuai dengan kebutuhan dan kemampuan sekolah. Untuk satuan pendidikan khusus, pelayanan konseling menekankan peningkatan kecakapan hidup sesuai dengan kebutuhan khusus peserta didik. Dalam pelaksanaannya, tentu ada kekhasan tersendiri di masing-masing sekolah berdasarkan kondisi lingkungan dan kebiasaan yang ada.

Pokok bahasan dalam pengembangan diri di sekolah dapat dicapai melalui kegiatan ekstrakurikuler dan bimbingan konseling. Ekstrakurikuler sebagai penunjang untuk mengimplementasikan minat dan bakat siswa, sedangkan bimbingan dan konseling sebagai cara untuk mengatasi permasalahan yang ditemui oleh siswa.Ekstrakurikuler merupakan jawaban atas tuntutan kebutuhan peserta didikuntuk membantu mereka agar dapat memperkaya lingkungan belajar serta menstimulus siswa agar lebih kreatif. ${ }^{5}$ Oleh karena itu, penting sekali melakukan kajian lebih mendalam kepada sekolah-sekolah yang memiliki kekhasan dalam melaksanakan ekstrakurikuler, sehingga dapat memperkaya khazanah keilmuan untuk kemajuan lembaga pendidikan.

Selain dari ekstrakurikuler, pengembangan diri siswa di sekolah juga dapat dilakukan melalui kegiatan bimbingan dan konseling.Bimbingan dan konseling ini bertujuan untuk memberikan dukungan perkembangan individu peserta didik secara optimal, mandiri dan bahagia. ${ }^{6}$ Dengan begitu, tujuan pendidikan baik yang direncanakan oleh instansi pendidikan maupun nasional dapat tercapai.Maka perlu adanya studi-studi secara khusus tentang bagaimana pengembangan diri di sekolah, khususnya sekolah yang memiliki ciri dan karakter khas tersendiri.

\footnotetext{
${ }^{3}$ Pusat Kurikulum Badan Penelitian dan Pengembangan Pendidikan Nasional, Model dan Contoh Pengembangan Diri Sekolah Menengah Pertama (Jakarta: Departement Pendidikan Nasional, 2007), 2.

${ }^{4}$ Ahmadi, Manajemen Kurikulum: Pendidikan Kecakapan Hidup (Yogyakarta: Pustaka Ifada, 2013).

${ }^{5}$ Slamet Nuryanto, “Manajemen Kegiatan Ektrakurekuler di SD Al Irsyad 01 Purwokerto", Jurnal Pendidikan, Vol. 5 No. 1 Mei 2017.

"Erisa, "Bimbingan dan Konseling di Sekolah; Prinsip dan Asas", Ristekdik: Jurnal Bimbingan dan Konseling, Volume 3 Nomor 2 (Juli-Desember 2018).
} 
Salah satu sekolah yang memiliki kekhasan tersendiri ialah SMP Negeri 3 Peterongan Jombang. Sekolah ini berada di lingkungan pesantren Darul Ulum. Hal yang menarik untuk diteliti ialah kegiatan pengambangan diri di SMP Negeri ini yang terwarnai dan kerjasama antara system pesantren dengan kesiswaan sekolah. Maka kiranya penting untuk diteliti lebih dalam bagaimana implementasi program pengembangan diri di SMP tersebut. Penelitian ini merupakan jenis penelitian kualitatif. Peneliti melakukan observasi, wawancara dari berbagai terkait dan melakukan dokumentasi baru dianalisa dengan deskriptif analitis.

\section{B. Program Pengembangan Diri, Kurikulum dan Sekolah}

Pengembangan diri merupakan kegiatan yang dilakukan di sekolah baik itu terprogram maupun tidak terprogram. Pengembangan diri diharapkan mampu menggali potensi peserta didik serta membentuk kepribadian dan tingkah laku yang baik. Sebagaimana yang tercantum dalam pedoman pengembangan diri Departemen Agama tahun 2005, disampaikan bahwa pengembangan diri diartikan sebagai proses pembentukan sikap dan perilaku yang relatif menetap melalui pengalaman yang berulang-ulang sampai pada tahap otonomi (kemandirian) mengenai suatu perilaku tertentu ${ }^{7}$ karena hakikatnya, siswa memiliki rasa ingin tahu yang besar dan sekolah harusnya menfasilitasi minat dan bakatnya.

Kegiatan pengembangan diri secara terprogram dilaksanakan dengan perencanaan khusus dalam kurun waktu tertentu untuk memenuhi kebutuhan peserta didik secara individual, kelompok dan atau klasikal melalui penyelenggaraan layanan dan kegiatan pendukung konseling dan kegiatan ekstra kurikuler. ${ }^{8}$ Sementara dalam kurikulum tingkat satuan pendidikan (KTSP), pengembangan diri juga merupakan satu komponen KTSP pada jenjang pendidikan dasar dan menengah, baik pada pendidikan umum, pendidikan kejuruan maupun pendidikan khusus. ${ }^{9}$ Walaupun pengembangan diri bagian dari komponen kurikulum tingkat satuan pendidikan (KTSP), namun tetap pengembangan diri bukanlah mata pelajaran dalam kurikulum. Fungsi guru di sini lebih kepada fasilitator dan konselor bukan sebagai pengajar.

Hal ini senada dengan apa yang dikatakan oleh Wina, bahwa pengembangan diri bukan merupakan mata pelajaran yang harus diasuh oleh guru. Pengembangan diri

${ }^{7}$ Departemen Agama, Pedoman Kegiatan Pengembangan Diri, 5.

${ }^{8}$ Departemen Pendidikan Nasional, Panduan Model Pengembangan Diri dalam https: / / luk.staff.ugm.ac.id/atur/KTSP-SMK/13.ppt. Diakses tanggal 2 Mei 2019.

9 E. Mulyasa, Kurikulum Tingkat Satuan Pendidikan: Sebuah Panduan Praktis (Bandung : PT.Remaja Rosda Karya), 283. 
bertujuanmemberikan kesempatan pada peserta didik untuk mengembangkan dan mengekspresikan diri sesuai dengan kebutuhan, bakat dan minat setiap peserta didik sesuai dengan kondisi sekolah. ${ }^{10}$

Berdasarkan beberapa pembahasan tentang definisi pengembangan diri di atas, maka dapat ditarik kesimpulan bahwa pengembangan diri merupakan bagian dari kurikulum yang pada pelaksanaannya bukan bagian dari mata pelajaran. Di sini minat dan bakat peserta didik benar-benar diarahkan sehingga dapat ditemukan spesialisasi bakat dan minatnya. Dengan demikian diharapkan nnti membentuk suatu tindakan dan tingakahlaku yang bermanfaat untuk masyarakat.

Ada beberapa tujuan dari kegiatan pengembangan diri ialah pertama, pengembangan diri secara umum untukmengembangkan potensi peserta didik secara optimal,yaitu menjadi manusia yang mampu menata diri danmenjawab berbagai tantangan dari dalam diri dan jugalingkungannya secara adaptif dan konstrukstif, baik dilingkungan keluarga maupun masyarakat.Kedua, tujuan khusus pengembangan diri untuk menunjangpendidikan peserta didik dalam mengembangkan: bakat,minat, kreativitas, kompetensi dan kebiasaan dalamkehidupan, kemampuan kehidupan keagamaan,kemampuan sosial, kemampuan belajar, wawasan danperencanaan karir, kemampuan pemecahan masalah dankemandirian. ${ }^{11}$

Sedangkan ruang lingkup pengembangan diri yang dapat dilaksanakan dapat dikelompokkan menjadi dua yaitu kegiatan yang terprogram dan tidak terprogram.Kegiatan terprogram meliputi kegiatan ekstrakurikuler dan bimbingan konseling. Sedangkan kegiatan yang tidak terprogram adalah kegiatan yang bersifat pembiasaan seperti salam, sapa, ibadah khusus keagamaan bersama dll.Pengembangan diri meliputi dua komponen yaitu pelayanan konseling, meliputi pengembangan kehidupan pribadi, kemampuan sosial, kemampuan belajar, wawasan dan perencanaan karir dan ekstra kurikuler meliputi kegiatan kepramukaan, latihan dasar kepemimpinan siswa (LDKS), palang merah remaja (PMR), pasukan pengibar bendera (PASKIBRA), kegiatan ilmiah remaja (KIR), seni dan budaya, olahraga, cinta alam, jurnalistik, teater, keagamaan, seminar, lokakarya, pameran/bazar. ${ }^{12}$

Secara operasional penerapan (implementasi) program pengembangan diri dapat dilakukan melalui beberapa pendekatan, yaitu penataan sosio kultur sekolah,

\footnotetext{
10 Lihat, Wina Sanjaya, Kurikulum dan Pembelajaran (Jakarta: Kencana, 2011).

11 Departemen Pendidikan Nasional Badan Penelitian Dan Pengembangan Pendidikan Nasional Pusat Kurikulum 2007 dalam https://currikicdn.s3-us-west-2.amazonaws.com/resourcefiles/54d2798eb3653.ppt. Diakses tanggal 2 Mei 2019.

12 Ibid.
} 
terpadu dalam proses belajar mengajar, terpadu dalam program bimbingan dan konseling : Pertama, Penataan Sosio-Kultural Sekolah. Sekolah merupakan lembaga pendidikan yang berupaya untuk membudayakan dan memberdayakan peserta didik. Di sini terkandung makna bahwa melalui pendidikan di sekolah, para peserta didik mampu mengembangkan dirinya secara utuh sebagai makhluk yang berdimensi biopsikososiospiritual (biologi, psychology, social, spiritual/agama). ${ }^{13}$

Untuk mencapai maksud tersebut, maka program pendidikan yang diselenggarakan di sekolah seyogyanya bersifat komprehensif dan integratif, tidak parsial. Sehubungan dengan hal itu, maka pengembangan kepribadian peserta didik tidak hanya sebatas menguasai konsep-konsep teoritik keilmuan, tetapi juga bagaimana konsep-konsep keilmuan yang diperoleh itu mempunyai makna dalam perilaku atau dapat dipraktekan di kehidupan sehari-hari. ${ }^{14}$ Kaitannya dengan hal itu, program pengembangan diri dipandang sebagai faktor yang dapat menjembatani kesenjangan yang terjadi antara teori dan praktek, maka program pengembangan diri ini melengkapi hal tersebut.

Sehubungan dengan hal itu, maka dalam mengimplementasikan program pengembangan diri, pihak sekolah perlu menciptakan iklim sosio-kultural yang kondusif, yang mendorong peserta didik untuk berperilaku sesuai dengan yang diharapkan. Caranya dengan mempraktekkan apa yang sudah diajarkan ke dalam kehidupan sehari-hari, terutama di sekolah. Artinya, teori yang sudah diperoleh ketika di kelas, diwujudkan dengan praktek. Selain itu, bagi para guru yang ada di sana juga menciptakan dan memberikan tauladan yang baik. Sehingga kondisi sosial di sekolah dengan kebudayaan yang diciptakan dapat berjalan sesuai dengan harapan. ${ }^{15}$

Kedua, Terpadu dalam proses belajar mengajar. Melalui mata pelajaran, para guru berupaya mengintegrasikan program pengembangan diri dengan materi-materi pelajaran yang relevan. Sehubungan dengan hal itu, maka guru terlebih dahulu perlu memahami program pengembangan diri tersebut. Contoh : kegiatan tahfidz dalah kegiatan pengembangan diri yang selaras dengan mata pelajaran PAl. Sehingga kegiatan tahfidz ini harus di tekankan dalam hal pelaksanaan dan kualitasnya. Ketiga, Terpadu dalam Program Bimbingan dan Konseling.Di sekolah-sekolah yang sudah menerapkan program bimbingan dan koseling dan tersedia guru pembimbingnya, maka program pengembangan diri ini diintegrasikan ke dalam program bimbingan tersebut.

\footnotetext{
${ }^{13}$ Hery Wibowo, Psikologi untuk Pengembangan Diri (Jakarta: Widya Padjadjaran, 2010).

${ }^{14}$ Depdikbud, Program Khusus Pengembangan Diri (Jakarta: Depdikbud, 2016).

15 Ibid.
} 
Dalam pelaksanaannya guru pembimbing perlu menyusun program pengembangan diri yang meliputi rumusan perencanaan, pelaksanaan, dan evaluasi. Terkait dengan lokasi 2 jam pembelajaran di kelas bagi program pengembangan diri, maka guru pembimbing adalah personel sekolah yang paling memungkinkan untuk mengisinya.

Keempat, Terpadu dalam Ekstra Kurikuler.Terpadu dalam Ekstra Kurikuler Kegiatan ekstrakurikuler merupakan salah satu bagian integral dan kurikulum yang memiliki nilai manfaat yang cukup besar bagi pengembangan pribadi peserta didik. Ekstra kurikuler ini dapat dijadikan wahana bagi penyelenggaraan program pengembangan diri. Dengan cara di dalam ekstra kurikuler tersebut diintegrasikan dengan arah kegiatan yang dapat mengembangkan diri siswa. Hal itu dapat di masukkan ke dalam metode ataupun materi yang sesuai.

Adapun beberapa bentuk kegiatan pengembangan diri yang dapat dilaksanakan di sekolah sebagai berikut: ${ }^{16}$ (1) Kegiatan rutin, yaitu memasukkan kegiatan yang dilakukan secara reguler, baik di kelas maupun di sekolah, yang bertujuan untuk membiasakan anak mengerjakan sesuatu dengan baik. Seperti: upacara bendera, senam, ibadah khusus keagamaan bersama, keberaturan, pemeliharaan kebersihan dan kesehatan diri. (2) Kegiatan Spontan, yaitu kegiatan pengembangan diri yang tidak ditentukan tempat dan waktunya seperti: membiasakan mengucapkan salam, membiasakan membuang sampah pada tempatnya, membiasakan antri. (3) Kegiatan Keteladanan, adalah kegiatan pengembangan diri yang mengutamakan pemberian contoh dari guru dan pengelola pendidikan yang lain kepada peserta didik seperti dalam bentuk perilaku sehari-hari seperti: berpakaian rapi, berbahasa yang baik, datang tepat waktu. (4) Kegiatan Terprogram, adalah kegiatan pembelajaranpengembangan diri yang diprogramkan dan direncanakan secara formal baik di dalam kelas maupun diluar kelas maupun sekolah yang bertujuan memberikan wawasan tambahan pada anak tentang unsure-unsur baru dalam kehidupan bermasyarakat yang penting untuk perkembangan anak. Seperti : Workshop, Kunjungan (Outing Class).

Berdasarkan beberapa pengertian di atas, maka setidaknya aktifitas pengembangan diri di sekolah dapat dilakukan dengan dua hal yaitu, kegiatan ekstrakurikuler dan bimbingan konseling.

16 Depdikbud, Program Khusus Pengembangan Diri (Jakarta: Depdikbud, 2016). 


\section{Program Ekstrakurekuler}

Dalam kamus besar Bahasa Indonesia, Ekstra adalah tambahan diluar yang resmi. Sedangkan Kurikuler adalah bersangkutan dengan kurikulum. Jadi pengertian ekstrakurikuler adalah kegiatan luar sekolah pemisah atau sebagian ruang lingkup pelajaran yang diberikan diperguruan tinggi atau pendidikan menengah tidak merupakan bagian integral dari mata pelajaran yang sudah ditetapkan dalam kurikulum. Kegiatan ekstrakurikuler merupakan kegiatan tambahan di luar struktur program di sekolah. ${ }^{17}$

Kegiatan ekstrakurikuler merupakan bagian dari pengembangan diri di sekolah. Kegiatan ini adalah untuk membantu peserta didik untuk mengembangkan diri sesuai dengan minat, bakat dan kebutuhan peserta didik. Kegiatan ekstrakurikuler harus dapat mengembangkan keterampilan baik secara terprogram maupun yang akan direncanakan ${ }^{18}$ kegiatan ekstrakurikuler merupakan jawaban atas tuntutan kebutuhan siswa dan membantu mereka untuk dapat memperkaya lingkungan belajar serta menstimulus siswa agar lebih kreatif. ${ }^{19} \mathrm{Di}$ samping untuk kebutuhan siswa dalam minat dan bakatnya, kegiatan ekstrakurikuler juga dapat berpengaruh dan berdampak positif terhadap prestasi belajar siswa. Yayan Inriani, dkk dalam hasil penelitiannya menyampaikan:

"kegiatan ekstrakurikuler memiliki program yang disesuaikan dengan kebutuhan siswa akan berdampak positif pada prestasi belajar siswa. Melalui kegiatan ekstrakurikuler yang baik maka siswa juga akan memiliki motivasi belajar yang tinggi. Seorang anak memiliki motivasi belajar yang tinggi, akan memengaruhi prestasi belajarnya. Sebaliknya, jika anak memiliki motivasi belajar yang rendah maka prestasi belajarnya pun akan rendah". ${ }^{20}$

Kegiatan ekstrakurikuler merupakan kegiatan yang dilakukan di luar kelas dan di luar pelajaran (kurikulum) untuk menumbuh kembangkan potensi sumber daya manusia (SDM) yang dimiliki peserta didik baik berkaitan dengan aplikasi ilmu pengetahuan yang didapatkannya maupun dalam pengertian khusus untuk membimbing peserta didik dalam mengembangkan potensi dan bakat yang ada dalam dirinya melalui kegiatan-kegiatan wajib maupun pilihan. ${ }^{21}$ Abdul Rachman

\footnotetext{
${ }^{17}$ B. Suryosubroto, Proses Belajar Mengajar di Sekolah (Jakarta: PT Rineka Cipta, 2002), 271.

${ }^{18}$ Ria Yuni, "Peran Kegiatan Ekstrakurikuler Dalam Mengembangkan WatakKewarganegaraan Peserta Didik", UCEJ, Vol. 1, No. 2 (Desember 2016).

${ }^{19}$ Slamet Nuryanto, “Manajemen Kegiatan Ektrakurekuler di SD Al Irsyad 01 Purwokerto”, Jurnal Pendidikan, Vol 5 No. 1 (Mei 2017).

${ }^{20}$ Yayan Inriani, dkk, "Pengaruh Kegiatan Ektrakurekuler terhadap Prestasi Belajar IPS melalui Motivasi Belajar", Jurnal Pendidikan: Teori, Penelitian dan Pengembangan, Volume 2 Nomor 7 (Juli Tahun 2017).

${ }^{21}$ Departemen Agama, Panduan Kegiatan Ekstrakurikuler (Jakarta: Direktorat Jendral Kelembagaan Agama Islam, 2005), 9.
} 
Saleh mengemukakan bahwa program ekstrakurikuler merupakan kegiatan pembelajaran yang diselenggarakan diluar jam pelajaran yang disesuaikan dengan kebutuhan pengetahuan, pengembangan, bimbingan dan pembiasaan siswa agar memiliki kemampuan dasar penunjang. ${ }^{22}$

Adapun tujuan dari pelaksanaan kegiatan ekstrakurikuler di sekolah menurut Direktorat Pendidikan Menengah Kejuruan yang dikutip oleh B. Suryosubroto adalah kegiatan ekstrakurikuler harus dapat meningkatkan kemampuan siswa beraspek kognitif, afektif, dan psikomotor. Mengembangkan bakat dan minat siswa dalam upaya pembinaan pribadi menuju pribadi manusia seutuhnya yang positif, dapat mengetahui, mengenal serta membedakan antara hubungan satu pelajaran dengan mata pelajaran lainnya. ${ }^{23}$

Kegiatan ekstrakurikuler dapat dikelompokkan menjadi beberapa jenis, yaitu: a) Krida, meliputi kepramukaan, Latihan Dasar Kepemimpinan Siswa (LDKS), Palang Merah Remaja (PMR), Pasukan Pengibar Bendera Pusaka (PASKIBRAKA); b) Karya Ilmiah, meliputi Kegiatan Ilmiah Remaja (KIR), kegiatan penguasaan keilmuan dan kemampuan akademik, penelitian; c) Latihan, lomba keterbakatan atau prestasi, meliputi pengembangan bakat olahraga, seni dan budaya, cinta alam, jurnalistik, teater, keagamaan; dan d) Seminar, lokakarya dan pameran atau bazaar, dengan substansi antara lain karier, pendidikan, kesehatan, perlindungan HAM, keagamaan, seni dan budaya. ${ }^{24}$

Proses pelaksanaan kegiatan ekstrakurikuler ini dilaksanakan melalui prinsipprinsip sebagai berikut: ${ }^{25}$ Individual, yaitu prinsip kegiatanekstrakurikuler yang sesuai dengan potensi, minat dan bakat peserta didik masing-masing.Pilihan, yaitu prinsip kegiatan ekstrakurikuler yang sesuai dengan keinginan dan diikuti secara sukarela peserta didik. Keterlibatan aktif, yaitu prinsip kegiatan ekstrakurikuler yang menuntut keikutsertaan peserta didik secara penuh.Menyenangkan, yaitu prinsip kegiatan ekstrakurikuler dalam suasana yang disukai dan menggembirakan peserta didik.Etos kerja, yaitu prinsip kegiatan ekstrakurikuler yang membangun semangat peserta didik untuk berkerja dengan baik dan berhasil.Kemanfaatan

\footnotetext{
${ }^{22}$ Abdul Rachman Saleh, Pendidikan Agama \& Pembangunan Watak Bangsa (Jakarta:PT. Raja Grafindo Persada, 2005), 170.

${ }^{23}$ Suryosubroto, Proses Belajar Mengajar di Sekolah (Jakarta: PT Rineka Cipta, 2002), 272.

${ }^{24}$ Muhaimin, dkk, Pengembangan Model Kurikulum Tingkat Satuan Pendidikan (KTSP) Pada Sekolah dan Madrasah (Jakarta: PT Raja Grafindo Persada, 2008).

25 Ibid.
} 
sosial, yaitu prinsip kegiatan ekstrakurikuler yang dilaksanakan untuk kepentingan masyarakat.

2. Program Bimbingan dan Konseling

Secara etimologi kata bimbingan merupakan terjemahan dari kata "guidance", berasal dari kata kerja "to guide” yang mempunyai arti "menunjukkan, membimbing, menuntun, dan membantu."Secara umum, bimbingan dapat diartikan sebagai suatu bantuan dan tuntunan. ${ }^{26}$ Tujuan pemberian layanan bimbingan dan konseling ialah: Pertama, Merencanakan kegiatan penyelesaian studi, perkembangan karir serta kehidupannya di masa yang akan datang. Kedua, Mengembangkan seluruh potensi dan kekuatan yang dimilikinya seoptimal mungkin. Ketiga, Menyesuaikan diri dengan lingkungan pendidikan, masyarakat, serta lingkungan kerjanya. Keempat, Mengatasi hambatan dan kesulitan yang dihadapi dalam studi, penyesuaian dengan lingkungan pendidikan, masyarakat, maupun lingkungan kerja. ${ }^{27}$ Peran guru bimbingan dan konseling adalah bertanggung jawab untuk membantu siswa agar dapat mengatasi masalah dengan mengikuti kegiatan bimbingan dan konseling. ${ }^{28}$

Ruang lingkup bimbingan dan konseling di sekolah dapat ditinjau dari berbagai segi yaitu segi fungsi, sasaran, layanan, dan masalah.Segi fungsi, bimbingan dan konseling di sekolah berfungsi untuk: pemahaman, pencegahan, pengentasan, pemeliharaan dan pengembangan; Segi sasaran, bimbingan dan konseling di sekolah diperuntukkan bagi seluruh siswa dengan tujuan agar siswa secara individual mencapai perkembangan optimal melalui kemampuan pengungkapan-pengenalan penerimaan diri dan lingkungan, pengambilan keputusan, pengarahan dan perwujudan diri; Segi pelayanan, bimbingan dan konseling mencakup pelayanan orientasi, informasi, penempatan/penyaluran, pembelajaran, konseling perorangan, bimbingan kelompok, konseling kelompok, serta kegiatan pendukung seperti aplikasi instrumentasi, himpunan data, konferensi kasus, kunjungan rumah, dan alih tangan

\footnotetext{
${ }^{26}$ Henny Juanita Christiani, Implementasi Pelayanan Bimbingan Dan Konseling di SD Swasta Kristen/Katolik seKecamatan Semarang Selatan (Semarang: Jurusan Bimbingan dan Konseling Fakultas Ilmu Pendidikan Universitas Negeri Semarang, 2012), 14.

27 Nurihsan dan Juntika, Dasar-dasar Bimbingan dan Konseling (Bandung: Mutiara. 2003), 13.

28 Zaini Tamin AR dan Subaidi, “Implementasi Segregasi Kelas Berbasis Gender dalam Menaggulangi Interaksi Negatif Siswa di SMP Al-Falah Ketintang Surabaya”, Al Hikmah : Jurnal Studi Keislaman, Vol. 9 No. 1 (2019): 30-43.
} 
kasus; Segi masalah, bimbingan dan konseling di sekolah mencakup empat bidang yaitu pribadi, sosial, belajar, dan karir. ${ }^{29}$

Materi bimbingan dan konseling di sekolah dasar termuat ke dalam bidangbidang dalam bimbingan dan konseling. Bidang bimbingan dan konseling di sekolah dasar menurut Prayitno yaitu bidang bimbingan pribadi, sosial, belajar, dan karir.Pertama, Bimbingan Pribadi, dalam bidang ini, pelayanan bimbingan dan konseling membantu siswa menemukan dan memahami serta mengembangkan pribadi yang beriman dan bertaqwa kepada Tuhan Yang Maha Esa, mandiri, aktif, dan kreatif, serta sehat jasmani, dan rohani.

Bidang bimbingan ini meliputi pokok-pokok materi berikut. 1). Pelaksanaan sikap dan kebiasaan dalam beriman dan bertaqwa terhadap Tuhan Yang Maha Esa. 2) Pengenalan dan pemahaman tentang kekuatan diri sendiri dan penyalurannya untuk kegiatan-kegiatan yang kreatif dan produktif, baik dalam kehidupan seharihari di sekolah, maupun untuk perannya di masa depan. 3) Pengenalan dan pemahaman tentang bakat dan minat pribadi serta penyaluran dan pengembangannya melalui kegiatan-kegiatan yang kreatif dan produktif. 4) Pengenalan dan pemahaman tentang kelemahan diri sendiri dan usaha-usaha penanggulangannya. 5) Pengembangan kemampuan mengambil keputusan sederhana dan mengarahkan diri.Ketujuh, Perencanaan serta penyelenggaraan hidup sehat.

Kedua, Bimbingan Sosial. Dalam bidang bimbingan sosial, pelayanan bimbingan dan konseling membantu siswa dalam proses sosialisasi untuk mengenal dan berhubungan dengan lingkungan sosial yang dilandasi budi pekerti luhur dan rasa tanggung jawab. Pengembangan kehidupan sosial, yaitu bidang pelayanan yang membantu peserta didik dalam memahami dan menilai serta mengembangkan kemampuan hubungan sosial yang sehat dan efektif dengan teman sebaya, anggota keluarga, dan warga lingkungan sosial yang lebih luas. Bidang bimbingan ini memuat pokok-pokok materi berikut: (1) Pengembangan kemampuan berkomunikasi baik melalui ragam lisan maupun tulisan secara efektif. (2) Pengembangan kemampuan bertingkah laku dan berhubungan social, baik dirumah, di sekolah, maupun dimasyarakat dengan menunjang tinggi tata karma, sopan santun serta nilai-nilai agama, adat, peraturan, dan kebiasaan yang berlaku.(3) Pengembangan hubungan yang dinamis dan harmonis serta produktif dengan teman sebaya.(4) Pengenalan

29 Dewa Ketut Sukardi dan Nila Kusmawati, Proses Bimbingan dan Konseling di Sekolah (Jakarta: Rineka Cipta, 2008), 9-14. 
dan pemahaman peraturan dan tuntutan sekolah, rumah dan lingkungan, serta kesadaran untuk melaksanakan. ${ }^{30}$

Ketiga, Bimbingan Belajar. Dalam bidang bimbingan belajar, pelayanan bimbingan dan konseling membantu siswa mengembangkan kebiasaan belajar yang baik dalam menguasai pengetahuan dan keterampilan, serta menyiapkannya untuk melanjutkan pendidikan pada tingkat yang lebih tinggi. Bidang bimbingan ini memuat pokok-pokok materi berikut:(1) Pengembangan sikap dan kebiasaan belajar untuk mencari informasi dari berbagai sumber belajar, bersikap terhadap guru dan narasumber lainnya, mengikuti pelajaran sehari-hari, mengerjakan tugas (PR), mengembangkan keterampilan belajar, dan menjalani program penilaian (2) Pengembangan disiplin belajar dan berlatih, baik secara mandiri maupun kelompok.(3) Pemantapan dan pengembangan penguasa materi pelajaran di sekolah dasar. (4) Orientasi belajar di Sekolah Menengah Pertama.

\section{Model Program Pengembangan Diri di SMP Negeri 3 Peterongan Jombang}

Pada pembahasan ini ditemukan bahwa program pengembangan diri di SMP Negeri 3 Peterongan Jombang diimplementasikan pada dua hal yaitu kegiatan ekstrakurikuler dan kegiatan bimbingan konseling.Dua kegiatan ini yang dilaksanakan sebagai program pengembangan diri untuk siswa SMP Negeri 3 Peterongan Jombang yang ditujukan untuk menggali bakat dan minat siswa serta untuk mengembangkannya. ${ }^{31}$

1. Ekstrakurikuler

Secara tanggungjawab program ekstrakurikuler di SMP Negeri 3 Peterongan Jombang ini dikawal dan dilaksanakan oleh Wakakesiswaan.Dari beberapa Program kegiatan ekstrakurikuler dilaksanakan oleh Pembina masing-masing ektra.Pembina ini ditentukan berdasarkan SK Pembina ekskul dari kepala sekolah.Pembina masingmasing kegiatan ekstrakurikuler dibawah kontrol waka kesiswaan.Dengan demikian seluruh yang bertanggungjawab atas semua kegiatan itu adalah waka kesiswaan.Berikut ini beberapa jenis ekstrakurikuler yang ada di SMP Negeri 3 Peterongan Jombang:Pramuka( WajibKelas VIII), Pembinaan OSN IPA, Pembinaan OSN Matematika, Pembinaan OSN IPS, Hafalan Al Quran ( MHQ), Tilawatil Qur'an (

\footnotetext{
30Prayitno, Pelayanan Bimbingan dan Konseling Sekolah Dasar (Padang: PT. Ikrar Mandiri Abadi, 1997), 65. ${ }^{31}$ Didik Supriadi, Koordinator BK, Wawancara, Jombang, 24 September 2019. 
MTQ), CCI / Keagamaan, SeniSamroh, SeniMarawis, SeniKaligrafi, Seni Batik, Sepak Bola, Bola Voly (Putra danPutri). ${ }^{32}$

"Pengembangan ini untuk mendukung sekolah menuju pada keunggulan prestasi contoh ektra OSN, matematika, ipa, ips ini kami ekskulkan kenapa maksunya, kedepan nanti ketika ada event event lomba anak ini sudah siap termasuk $\mathrm{CCl}$, cci itu kami ekskulkan karena smp 3 punya keunggulan di juara naasional, kemarin di aceh, pada bulan oktober, juga jara satu di aceh. ${ }^{33}$

Adapun jadwal pelaksanann kegiatan ekstrakurikuler yang diterapkan di SMP Negeri 3 Peterongan Jombang ini adalah pada hari sabtu dan minggu mulai pukul 14.00 wib sampai dengan 16.00 wib. Kegiatan ekstrakurikuler seperti bola volly didampingi oleh seorang Pembina. Begitu juga dengan kegiatan ekstrakurikuler pramuka, ada Pembina yang mengawal dan membina kegiatan tersebut.Pada tahapan pelaksanaan ini kesiswaan sebagai supervisor. Kesiswaan melakukan kontrol ke tiap-tiap pelaksanaan kegiatan ekstrakurikuler yang dilakukan. Beberapa instrument atau kelengkapan yang absensi kehadiran. ${ }^{34}$

Pada pelaksanaan kegiatan ekstrakurikuler khususnya kejuaraan atau olahraga biasanya dilaksanakan menyesuaikan acara besar yaitu bersifat event.Seperti kegiatan olahraga sepak bola, bola volly dll.Salah satu kesiswaan di SMP Negeri 3 Peterongan Jombang mengatakan:

“Jika kami selalu membuat program,itu kami awali bulan agustus karena memang beberapa ivent itu pertandinganya kan sekitar agustus termasuk peringatan atau perayaan HUT RI, Liga Unit....."35

Untuk sampai pada pelaksanaan kegiatan ektrakuler, ada beberapa tahapan yang dilakukan.Pertama, tahap perencanaan. Untuk medapatkan perencanaan yang bagus, diawali dengan evaluasi pelaksanaan ekstrakurikuler tahun lalu kemudian menghasilkan rekomendasi program ektrakulerkuler tahun berjalan.

"Pengembangan yang mengacu pada potensi anak-anak, mengevaluasi dari program yang kemarin, mana yang dibutuhkan sebagai program pengembangan dan mana yang program ini yang menjadi program keunggulan sekolah". ${ }^{36}$

Kedua, tahapan pengelompokan. Pada tahapan pengelompokan ini ditujukan agar mempertimbangkan efektifitas kegiatan. Misalnya salah satunya adalah dengan dibentuknya pengelompokan satu pembinaan atau kelas hanya 15 anak. Selain itu, instrument seperti absensi, buku dan perlengkapan lainnya juga dipersiapkan pada

\footnotetext{
32Dokumen Program Kegiatan Ekstrakurikuler SMP Negeri 3 Peterongan Jombang Tahun 2019-2020.

${ }^{33}$ Safak Efendi, Kepala Sekolah, Wawancara, Jombang, 3 Desember 2019.

${ }^{34}$ Hasil Observasi penulis di SMP Negeri 3 Peterongan Jombang.

${ }^{35}$ Miftakhul Rohana, Waka Kesiswaan, Wawancara, Jombang, 8 Oktober 2019.

${ }^{36}$ Safak Efendi, Kepala Sekolah, Wawancara, Jombang, 3 Desember 2019.
} 
tahapan ini.Masing-masing kelompok diberi satu Pembina. ${ }^{37}$ Untuk mencapai kesesuain kelompok berdasarkan minat dan bakatnya, siswa diberi kebebasan dalam memilih.Bahkan, siswa diberi waktu selama 2 minggu untuk berkonsultasi dan minta pendapat pada orang tuanya.

"Program kami begini, ana-anak saat kami memberi pengarahan, memberi gambaran tentang ekskul yang ada di SMP 3, itu kami tayangkan termasuk prestasi-prestasinya anak-anak kami beri waktu sekitar 2 minggu untuk menggali untuk berfikir kira-kira saya mampunya di mana karena setelah itu saya tidak mengijinkan untuk ganti ekskul, waktu dua minggu itu silahkan konsultasi dengan orang tua, kembali menggali bakatnya, waktu mo situ saya beri brousur pilihan..." ${ }^{38}$

Dalam hal pengelompokan ini, sangat memperhatikan minat dan bakat siswa.siswa yang kecondongan dengan matematika dikelompokkan berdasarkan minatnya pada matematika begitu juga dengan minat-minat lainnya. Biasanya, untuk mengetahui kelompok ini diawali dari pertama kali daftar atau masuk tahun ajaran baru.

"Pengelompokan siswa: Pada waktu ekstra kalau menjurus ke matematika, maka diikutkan ke matematika. Pembelajaran tetap klasikal biasa. Klas ini besiknya apa, kelas ini besiknya apa. Kelas, kalau kemampuan di mana, baru diarahkan. Melalui tes.Tes di awal masuk, begitu diterima, tes IQ, tes mapel. Tes Pendidikan Awal (TPA) mengacu pada dinas, karena dibawah naungan dinas. OSN misalnya pesertanya 30, mungkin diambil 10..pramuka wajib semua berdasarkan permend.Kurikulum kepondokan: BCA, al-Quran,SKI, B. Arab 123, fiqih 123, Kurikulum 42 jam dinas, 9 pondok. Meskipun kita dinas, tetap rekomendasi dari pondok. Kurikulum bela diri tidak diperbolehkan.90\% dari luar, yang $5 \mathrm{~km}$ dari pondok harus mondok." 39

Ketiga, pada tapan pelaksanaan. Tahapan ini di mana siswa berlatih bersama Pembina. Pelaksanaan ini diawali dengan doa bersama dilanjutkan dengan aktifitas pengembangan diri dan ditutup dengan doa. ${ }^{40} \mathrm{Di}$ antara respon siswa secara umum dari aktifitas ekskul yang ada, ia merasa senang bergembira, Pembina yang membimbing penuh menyenangkan.

"Saya ekskul IPA dua kali pertemuan yaitu hari sabtu dan minggu, Alhamdulillah enak, selain saya ikut lomba-lomba di tingkat kabupaten maupun nasional itu dapat ilmu buat nyari SMA besok...."41 "Saya suka matematika karena ada kepuasan tersendiri ketika sudah memecahkan satu soal, gurunya nyaman menyampaikan dan sabar kalau saya belum bisa mengerjakan itu saya dibimbing sampe bisa...". ${ }^{42}$

\footnotetext{
${ }^{37}$ Hasil Observasi penulis di SMP Negeri 3 Peterongan Jombang

${ }^{38}$ Miftakhul Rohana, Waka Kesiswaan, Wawancara, Jombang, 8 Oktober 2019.

${ }^{39}$ Miftakhul Rohana, Waka Kesiswaan, Wawancara, Jombang, 18 Nopember 2019.

${ }^{40}$ Hasil Observasi penulis di SMP Negeri 3 Peterongan Jombang.

${ }^{41}$ Badwa Dava, Siswa kelas 8, Wawancara, Jombang, 29 Oktober 2019.

${ }^{42}$ Muhammad Akta, Siswa kelas 8, Wawancara, Jombang, 29 Oktober 2019.
} 
Keberadaan guru sangat menentukan dengan berhasil atau tidaknya pembinaan ekstrakurikuler yang dilakukan.Oleh karena itu guru sangat mutlak diperlukan.Selain itu, keberhasilan juga sangat dipengaruhi oleh kretifitas guru dalam menyampaikan.Namun, secara rata-rata pelaksanaan ektrakrekuler tercapai dengan baik. Walaupun tidak lepas dari beberapa kendala yang dihadapi.

"Rata-rata tercapai, sesuai kecuali kendala itu kadang-kadang dari sekolah sendiri misalnya ada kegiatan sekolah sampai sore. Akhirnya Pembina tidak bisa menyelesaikan satu meteri yang ditargetkan pada waktu, itu juga kendala hujan terutama basket, volley sepak bola. Kalau hujan anak-anak diberi teori di dalam sekolah". ${ }^{43}$

\section{Kegiatan Bimbingan dan Konseling}

Bimbingan dan konseling di SMPN 3 ini merupakan kegiatan yang penting.Di antara tujuan dari BK ialah untuk terbilang memiliki tugas cukup berat, di mana guru BK yang bertanggungjawab atas penyelesaian permasalahan siswa.Dengan BK ini siswa dapat dikembangkan sesuai minat dan bakatnya. hal ini diakui oleh bagian kesiswaan.

"BK ini pengembangan dirinya justru sangat penting bagi kami, karena dalam bk itu adalah catatan pengembangan hakiki bagi anak-anak, pembinaan pribadi bagi anakanak, ini sangat penting shingga anak-anak itu bukan hanya rata-rata siapa yang dipanggil BK itu adalah anak bermasalah bagi kami, anak-anak itu harapan saya bukan BK yang memanggil, anak-anak minta bagaimana pembinaan terhadap pribadinya. ...". 44

Namun, disamping bertugas konseling, BK juga diharuskan juga untuk memberikan rekomendasi dan penilaian bersama-samaguru dan wali kelas.

Disamping konseling, bk itu membuat penilaian dalam bentuk jurnal, bersama dengan wali kelas, bersama dengan guru mata pelajaran, sudah kami sistim, bapak ibu wali kelas mengumpulkan jurnal ke bk setiap akhir bulan, dengan format yang sudah saya berikan, wali kelas tinggal ngisi saja guru maple tinggal ngisi saja dikumpulkan pada guru bk masing-masing dari koordinator BK. ${ }^{45}$

Pelaksanaan Bimbingan dan Konseling di SMP Negeri 3 Peterongan Jombang termuat pada beberapa layanan, di antaranya layanan (1) layanan dasar, (2) layanan permintaan dan perencanaan individual, (3) Layanan Responsif, dan (4) dukungan sistem. ${ }^{46}$

Pertama, layanan dasar pada sekolah dasar dilaksanakan dalam aktivitas yang langsung diberikan kepada peserta didik/konseli adalah bimbingan kelompok,

\footnotetext{
${ }^{43}$ Miftakhul Rohana, Waka Kesiswaan, Wawancara, Jombang, 18 Nopember 2019.

${ }^{44}$ Safak Efendi, Kepala Sekolah, Wawancara, Jombang, 3 Desember 2019.

${ }^{45}$ Safak Efendi, Kepala Sekolah, Wawancara, Jombang, 3 Desember 2019.

${ }^{46}$ Dokumen rencana program BK SMP Kelas dalam 2019.
} 
bimbingan klasikal, dan bimbingan lintas kelas. Aktivitas yang dilaksanakan melalui media adalah papan bimbingan, leaflet dan media inovatif bimbingan dan konseling.Bagi guru kelas yang menjalankan fungsi sebagai guru bimbingan dan konseling, layanan bimbingan klasikal dapat diintegrasikan dalam kegiatan pembelajaran tematik. ${ }^{47}$

Kedua, Layanan permintaan. Layanan ini bertujuan untuk membantu peserta didik belajar memantau dan memahami pertumbuhan dan perkembangannya sendiri dan mengambil tindakan secara proaktif terhadap informasi tersebut.Layanan peminatan dan perencanaan individual berisi aktivitas membantu setiap peserta didik untuk mengembangkan dan meninjau minat dan perencanaan pribadi, sosial, belajar, dan karir. ${ }^{48}$

Aktivitas layanan perminatan dan perencanaan individual yang langsung diberikan kepada peserta didik dapat berupa kegiatan bimbingan klasikal, konseling individual, konseling kelompok, bimbingan kelas besar atau lintas kelas, bimbingan kelompok, konsultasi dan kolaborasi. Aktivitas peminatan dan perencanaan individual di Sekolah Dasar terintegrasi dengan kegiatan ekstrakurikuler. Pemilihan kegiatan ekstrakurikuler juga dapat menggambarkan minat peserta didik pada aktivitas tertentu. Guru bimbingan dan konseling atau konselor dapat memberikan informasi tentang perencanaan pribadi, akademik dan karir dalam pemilihan kegiatan ekstra kurikuler bagi peserta didik.

Ketiga, layanan responsif.Layanan responsif adalah layanan untuk memenuhi kebutuhan jangka pendek peserta didik, atau masalah-masalah yang dialami peserta didik/konseli yang bersumber dari lingkungan kehidupan pribadi, sosial, belajar, dan karir.Layanan terdiri atas konseling individual, konseling kelompok, konsultasi, konferensi kasus, referal dan advokasi.Sementara aktivitas layanan responsif melalui media adalah konseling melalui elektronik dan kotak masalah.Selain dari bentuk layanan, BK juga aktif secara langsung mendatangi dan memanggil siswa yang bermasalah.

"Kita harus menjemput bola, makanya kita panggil, kadang anak dating sendiri ke BK, ada maslah kita bantu tetapi persentasinya sedikit sekali. Untuk kasus ringan BK saja dengan wali kelas.Bahkan kadang sampek ke asrama pondok". ${ }^{49}$

\footnotetext{
${ }^{47}$ Dokumen rencana program BK SMP Kelas dalam 2019.

${ }^{48}$ Dokumen rencana program BK SMP Kelas dalam 2019.

${ }^{49}$ Hasil Wawancaran dengan salah satu guru BK SMN 3 Peterongan Jombang. 
Layanan permintaan yang dilakukan oleh siswa yaitu mereka datang langsung ke guru BK untuk meminta penyelesaian permasalahannya.la menceritakan apa saja keluhan yang dihadapi, guru BK mendengarkan memberi saran. Hal-hal yang berkaitan dengan bagian lain, guru BK mengkordinasikan dengan guru kelas dan kesiswaan untuk mengatasi masalah anak tersebut. ${ }^{50}$

Keempat, dukungan sistem merupakan komponen pelayanan dan kegiatan manajemen, tata kerja infrastruktur dan pengembangan keprofesionalan konselor secara berkelanjutan yang secara tidak langsung memberikan bantuan kepada peserta didik atau memfasilitasi kelancaran perkembangan peserta didik. Aktivitas yang dilakukan dalam dukungan sistem adalah (1) administrasi, yang di dalamnya termasuk melaksanakan dan menindaklanjuti asesmen, kunjungan rumah, menyusun dan melaporkan program bimbingan dan konseling, membuat evaluasi, dan melaksanakan administrasi dan mekanisme bimbingan dan konseling, serta (2) kegiatan tambahan dan pengembangan profesi, bagi konselor atau guru kelas yang berfungsi sebagai guru bimbingan dan konseling, kegiatan pengembangan profesi dilaksanakan sesuai dengan tugasnya sebagai guru kelas dengan diperkaya oleh kegiatan pelatihan atau lokakarya tentang bimbingan dan konseling untuk memperkuat kompetensi dalam menjalankan fungsi sebagai guru bimbingan dan konseling atau konselor. ${ }^{51}$

Ada beberapa hal dari pengamatan yang ditemukan Pelaksanaan bimbingan dan konseling di SMP Negeri 3 Peterongan Jombang, selain dari menyelesaikan siswa-siswi yang bermasalah, juga yang ditekankan adalah fungsi pencegahan. Ada hal yang unik dan menarik yang dalam pelaksanaan bimbingan dan konseling di SMP Negeri 3 ini, yaitu adanya kerjasama antara guru BK dan seluruh komponen sekolah dengan pihak keamanan pondok. Artinya untuk maksimalisasi penanganan permasalahan siswa-siswa lebih mudah.seperti contoh kasus seperti pacaran yang tergolong pelanggaran berat:

"kita itu menerima laporan, dari guru, kesiswaan, pengurus asrama, masih kterkaitan kerjasama antara kesiswaan, kamtib, bk dan guru kelas dan siswa yang ada di sini..."52

Di antara fungsi pencegahan yang dilaksanakan di SMP Negeri 3 ini, adanya aturan pemisahan kegiatan intraksi laki-laki dan perempuan. Pencegahan dalam hal ini agar siswa-siswi terhindar dari pacaran dan perzinahan. Di SMP ini, pacaran tidak

\footnotetext{
${ }^{50} \mathrm{Hasil}$ pengamatan penyelesaian masalah anak oleh guru BK.

${ }^{51}$ Dokumen rencana program BK SMP Kelas dalam 2019.

52Didik Supriadi, Koordinator BK, Wawancara, Jombang, 24 September 2019
} 
hanya dilarang, akan tetapi pelanggaran berat. Dalam upaya pencegahannya di SMP ini terbilang unik, karena guru BK tidak sendirian dalam mengatasi masalah tersebut, akan tetapi juga dibantu oleh pihak di luar manajemen sekolah yaitu pondok pesantren Darul Ulum.

"kalau di sini memang unik, karena di pondok, jadi selain kesiswaan juga kamtib, kalau ada pelanggaran langsung ada kamtibnya. Langsung dihukum oleh keamanan. Pelanggaran berat, ringan dan sedang. Berat ya pacaran, pelanggaran sedang ya keluar pondok tampa ijin.."53

Menurut waka kesiswaan, rata-rata siswa lebih banyak berasal dari dalam asrama, sehingga diperlukan kerjasama yang kuat dengan pihak pondok.

"Siswa hampir 90 \% asrama, 10 \% luar asrama, kendala-kendala yang ada adalah persoalan waktu, kadang terkendala kegiatan pondok". ${ }^{4}$

Adapun dari segi sasaran, bimbingan dan konseling di SMP Negeri 3 Peterongan Jombang adalah untuk seluruh siswa. Artinya semua siswa dapat hal dan layanan yang sama dalam hal mengatasi seluruh permasalahannya.

Berdasarkan contoh pelaksanaan seperti yang disampaikan oleh salah satu guru BK tersebut. Pokok-pokok materi bimbingan dan konseling yang dilaksanakan di SMP Negeri 3 Peterongan Jombang juga sudah masuk pada pokok-pokok yang harus ada dalam bimbingan. Seperti yang tercantum dalam rencana kegiatan seperti layanan pribadi, layanan sosial dan layanan belajar. Seperti yang penulis lihat secara langsung, ada salah satu siswa yang datang langsung kepada BK untuk berkonsultasi. Melaporkan permasalahannya dan meminta solusi. Hal ini juga sesuai dengan harapan yang diharapkan oleh kepala sekolah bahwa diharapkan bukan guru BK yang mencari siswa yang bermasalah akan tetapi siswa yang mendatangi guru untuk berkonsultasi mencari solusi atas permasalahannya.

\section{Kesimpulan}

Model program pengembangan diri di SMP Negeri 3 Peterongan Jombang dilaksanakan dengan dua hal, yaitu program ekstrakurekuler dan bimbingan konseling. Pelaksanaan kegiatan ektrakurekuler yang dilaksanakan di SMP Negeri 3 Peterongan Jombang, diawali dengan beberapa tahapan, yaitu: Pertama, tahap perencanaan dengan mengevaluasi program ektrakurekuler tahun sebelumnya dan menghasilkan rekomendasi untuk tahun berjalan. Kedua, tahap pengelompokan, di mana sebelum

${ }^{53}$ Didik Supriadi, Koordinator BK, Wawancara, Jombang, 24 September 2019

${ }^{54}$ Sunarko, Waka Kurikulum, Wawancara, Jombang, 24 September 2019 
kegiatan dilaksanakan siswa dikelompokkan berdasarkan minat dan bakatnya. Ketiga, tahap pelaksanaan, yaitu aktifitas program ektrakurekuler dilaksanakan. Pada tahap pelaksanaannya, kegiatan ektra dilaksanakan pada hari sabtu dan minggu dengan didampingi oleh Pembina. Penanggungjawab dalam hal ini adalah waka kesiswaan. Bimbingan yang dilakukan guru BK mengacu kepada kebutuhan. Kebutuhan yang penulis maksud adalah berdasarkan penelitian atau survey terlebih dahulu. Ada empat layanan yang diterapkan yaitu (1) layanan dasar, (2) layanan permintaan dan perencanaan individual, (3) Layanan Responsif, dan (4) dukungan sistem.

\section{E. Referensi}

Ahmadi. Manajemen Kurikulum: Pendidikan Kecakapan Hidup. Yogyakarta: Pustaka Ifada, 2013.

AR, Zaini Tamin., Subaidi. "Implementasi Segregasi Kelas Berbasis Gender dalam Menaggulangi Interaksi Negatif Siswa di SMP Al-Falah Ketintang Surabaya", Al Hikmah : Jurnal Studi Keislaman, Vol. 9 No. 1 (2019).

Christiani, Henny Juanita. Implementasi Pelayanan Bimbingan Dan Konseling di SD Swasta Kristen/Katolik Se-Kecamatan Semarang Selatan. Semarang: Jurusan Bimbingan Dan Konseling Fakultas Ilmu Pendidikan Universitas Negeri Semarang, 2012.

Departemen Agama. Panduan Kegiatan Ekstrakurikuler. Jakarta: Direktorat Jendral Kelembagaan Agama Islam, 2005.

Depdikbud. Program Khusus Pengembangan Diri. Jakarta: Depdikbud, 2016.

Departemen Pendidikan Nasional. Panduan Model Pengembangan Diri dalam https: / / luk.staff.ugm.ac.id/atur/KTSP-SMK/13.ppt. Diakses tanggal 2 Mei 2019.

Dokumen Program Kegiatan Ekstrakurikuler SMP Negeri 3 Peterongan Jombang Tahun 2019-2020.

Dokumen Rencana Program Bimbingan Konseling SMP Negeri 3 Peterongan Jombang dalam 2019.

Erisa. "Bimbingan dan Konseling di Sekolah; Prinsip dan Asas", Ristekdik: Jurnal Bimbingan dan Konseling, Volume 3 Nomor 2 (Juli-Desember 2018).

Inriani, Yayan., dkk. "Pengaruh kegiatan ektrakurekuler terhadap prestasi belajar IPS melalui motivasi belajar", Jurnal Pendidikan: Teori, oenelitian dan Pengembangan Volume 2 Nomor 7 (Juli Tahun 2017).

Muhaimin, dkk. Pengembangan Model Kurikulum Tingkat Satuan Pendidikan (KTSP) Pada Sekolah dan Madrasah. Jakarta: PT Raja Grafindo Persada, 2008.

Mulyasa, E. Kurikulum Tingkat Satuan Pendidikan: Sebuah Panduan Praktis. Bandung : PT.Remaja Rosda Karya. 
Nurihsan dan Juntika. Dasar-dasar Bimbingan dan Konseling. Bandung: Mutiara. 2003.

Nuryanto, Slamet. "Manajemen Kegiatan Ektrakurekuler di SD Al Irsyad 01 Purwokerto”, Jurnal Pendidikan, Vol 5 No.1 (Mei 2017).

Prayitno. Pelayanan Bimbingan dan Konseling Sekolah Dasar. Padang: PT. Ikrar Mandiri Abadi, 1997.

Pusat Kurikulum Badan Penelitian Dan Pengembangan Pendidikan Nasional. Model dan Contoh Pengembangan Diri Sekolah Menengah Pertama. Jakarta: Departement Pendidikan Nasional, 2007.

Rachman Saleh, Abdul. Pendidikan Agama \& Pembangunan Watak Bangsa. Jakarta: PT. Raja Grafindo Persada, 2005.

Sanjaya, Wina. Kurikulum dan pembelajaran. Jakarta: Kencana, 2011.

Sukardi, Dewa Ketut., dan Nila Kusmawati. Proses Bimbingan danKonseling di Sekolah. Jakarta: Rineka Cipta, 2008.

Suryosubroto. Proses Belajar Mengajar Di Sekolah. Jakarta: PT Rineka Cipta, 2002.

Wibowo, Hery. Psikologi untuk Pengembangan Diri. Jakarta: Widya Padjadjaran, 2010.

Yuni, Ria. "Peran Kegiatan Ekstrakurikuler Dalam Mengembangkan Watak Kewarganegaraan Peserta Didik”, UCEJ, Vol. 1, No. 2, (Desember 2016).

\section{Hasil Wawancara}

Safak Efendi, Kepala Sekolah, Wawancara, Jombang, 3 Desember 2019.

Miftakhul Rohana, Waka Kesiswaan, Wawancara, Jombang, 8 Oktober 2019.

Sunarko, Waka Kurikulum, Wawancara, Jombang, 24 September 2019.

Didik Supriadi, Koordinator BK, Wawancara, Jombang, 24 September 2019.

Badwa Dava, Siswa kelas 8, Wawancara, Jombang, 29 Oktober 2019.

Muhammad Akta, Siswa kelas 8, Wawancara, Jombang, 29 Oktober 2019. 